\title{
Analysis of a C-methyltransferase gene (aviG1) involved in avilamycin biosynthesis in Streptomyces viridochromogenes Tü57 and complementation of a Saccharopolyspora erythraea eryBIII mutant by aviG1
}

\author{
G. Weitnauer, ${ }^{1}$ S. Gaisser, ${ }^{2}$ L. Kellenberger, ${ }^{2}$ P. F. Leadlay ${ }^{2}$ \\ and A. Bechthold ${ }^{1}$
} Author for correspondence: A. Bechthold. Tel: +49 761 2038371. Fax: +49 7618383.
e-mail: andreas.bechthold@uni-freiburg.de

\footnotetext{
1 Albert-Ludwigs-Universität Freiburg, Institut für Pharmazeutische Biologie, Stefan-Meier Str. 19, 79104 Freiburg, Germany

2 Cambridge Centre for Molecular Recognition and Department of Biochemistry, University of Cambridge, Tennis Court Road, Cambridge CB2 1GA, UK
}

\begin{abstract}
Streptomyces viridochromogenes Tü57 is the principal producer of avilamycin A. aviG1, a putative methyltransferase gene, was detected in the avilamycin biosynthetic gene cluster. To determine the function of aviG1, a targeted gene inactivation experiment was performed. The resulting chromosomal mutant, carrying an in-frame deletion in aviG1, was deficient in avilamycin production. aviG1 was used to complement an eryBIII mutant of the erythromycin A producer Saccharopolyspora erythraea [Gaisser, S., Bohm, G. A., Doumith, M., Raynal, M. C., Dhillon, N., Cortes, J. \& Leadlay, P. F. (1998). Mol Gen Genet 258, 78-88]. The presence of erythromycin A in the culture supernatant of the complemented mutant indicated that L-mycarose biosynthesis could be restored and that AviG1 could take over the function of the C-methyltransferase EryBIII.
\end{abstract}

Keywords: avilamycin A, erythromycin, deoxysugar biosynthetic genes, methyltransferase

\section{INTRODUCTION}

Avilamycin A and avilamycin C (Fig. 1) are oligosaccharide antibiotics belonging to the orthosomycin group (Buzzetti et al., 1968). Like ziracin, another orthosomycin, which has been tested in clinical trials against human infectious diseases (Foster \& Rybak, 1999; Fuchs et al., 1999; Jones et al., 1999; Lin et al., 2000; Wang et al., 2000), avilamycin is a potent antibiotic with excellent activity against Gram-positive bacteria (Wright, 1979). The biosynthesis of avilamycin A requires the formation of a polyketide moiety and its attachment to a heptasaccharide chain consisting of D-olivose, 2-deoxy-Devalose, 4-O-methyl-D-fucose, 2,6-di-O-methyl-D-mannose, L-lyxose and (methyl) eurekanate. As for many antibiotics, the cloning of the avilamycin biosynthetic genes has been facilitated by the fact that they are organized in a cluster. The complete avilamycin biosynthetic gene cluster has been sequenced and several genes

Abbreviation: ES-MS, electrospray mass spectrometry.

The GenBank accession number for the sequence reported in this paper is AF333038. have been characterized (Gaisser et al., 1997; Weitnauer et al., 2001). Expression of one of these genes, encoding a polyketide synthase, in Streptomyces lividans resulted in the production of orsellinic acid. It was also shown that insertional inactivation of a putative $\mathrm{dNDP}$-glucose 4,6-dehydratase gene (aviE1) abolished avilamycin A production. Targeted gene disruption of two other genes, aviG4 and aviH, encoding a methyltransferase and a halogenase, respectively, led to the production of avilamycin derivatives with an incomplete dichloroisoeverninic moiety.

In contrast to avilamycin $\mathrm{A}$, in which a long sugar side chain is connected to a small polyketide moiety, erythromycin is a macrolide polyketide, to which only two separate sugar residues (L-mycarose and D-desosamine) are transferred (Fig. 1). The biosynthesis of erythromycin is well understood and many mutants containing deletions in single biosynthetic genes are available (Paulus et al., 1990; Haydock et al., 1991; Weber et al., 1991; Stassi et al., 1993; Lambalot et al., 1995; Summers et al., 1997; Salah-Bey et al., 1998; Gaisser et al., 1998). eryB genes have been shown to be involved in dTDP-mycarose biosynthesis. One of these 


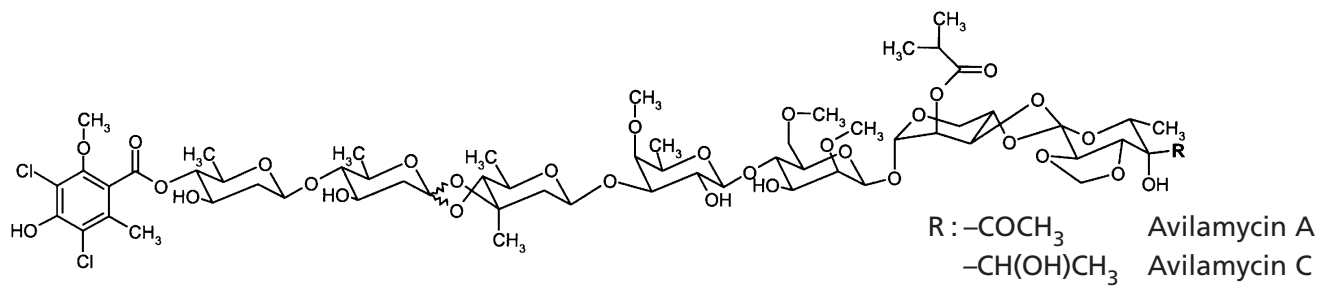

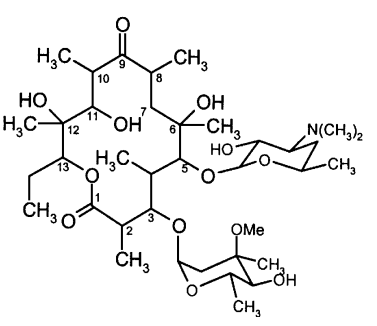

Erythromycin A
Fig. 1. Structure of avilamycin A, avilamycin $\mathrm{C}$ and erythromycin $\mathrm{A}$. genes, eryBIII, encodes a C-methyltransferase involved in methylation at position C3 during dTDP-L-mycarose biosynthesis (Gaisser et al., 1998).

For better understanding of the biosynthesis of avilamycin A we have initiated the characterization of another gene (aviG1) of the avilamycin biosynthetic gene cluster located upstream of the avilamycin polyketide synthase biosynthetic gene. The deduced amino acid sequence of aviG1 was very similar to EryBIII. The involvement of AviG1 in the biosynthesis of avilamycin A was demonstrated by targeted gene disruption and complementation of an eryBIII mutant of Saccharopolyspora erythraea.

\section{METHODS}

Bacterial strains, plasmids and culture conditions and materials. Streptomyces viridochromogenes Tü57 (Buzzetti et al., 1968), obtained from the Department of Microbiology, University of Tübingen, Germany, was grown on $1 \%$ malt extract, $0.4 \%$ yeast extract, $0.4 \%$ glucose and $1 \mathrm{mM} \mathrm{CaCl}_{2}$, $\mathrm{pH} 7 \cdot 2$ (HA medium) at $37^{\circ} \mathrm{C}$. For production of avilamycins, spores of Str. viridochromogenes Tü57 were transferred to $\mathrm{NL} 19+$ medium containing $2 \%$ mannitol, $2 \%$ soya flour and $20 \mathrm{mM}$ L-valine (pH 7.2) and were grown at $28{ }^{\circ} \mathrm{C}$ in $500 \mathrm{ml}$ baffled flasks filled with $100 \mathrm{ml}$ medium at 180 r.p.m. for $48 \mathrm{~h}$. The erythromycin-producing red variant strain of Sac. erythraea NRRL2338 (Hessler et al., 1997) was kindly provided by J. M. Weber, FermaLogic, Chicago, IL, USA. For optimal production of erythromycin A and its derivatives, $\mathrm{Sac}$. erythraea NRRL2338, the eryBIII mutant 335 and the eryBIII mutant 335 containing aviG1 were grown at $30{ }^{\circ} \mathrm{C}$ as described previously (Gaisser et al., 1998). DNA manipulation was performed in Escherichia coli XL-1 Blue MRF from Stratagene. Plasmids were passed through E. coli ET12567 (dam $d c m^{-} h s d S^{-} \mathrm{Cm}^{+}$) (Flett et al., 1997) to generate unmethylated DNA before being transferred into Str. viridochromogenes Tü57. E. coli strains were grown under standard conditions. pBluescript SK- (pSK-) was obtained from Stratagene, plasmids pUC18, pUC19 and pSP1, carrying the erythromycin resistance gene (Pelzer et al., 1997), were provided by S. Pelzer, University of Tübingen, Germany, and pSET152 (Biermann et al., 1992) was obtained from Eli Lilly. The construction of the expression plasmid pSG142 has been described previously (Gaisser et al., 2000). Plasmids used in this study are listed in Table 1.

Medium components were purchased from Hartge Ingredients and restriction enzymes were from Amersham Pharmacia. Avilamycin A was a gift from Eli Lilly, carbenicillin was from Roth, and apramycin and erythromycin were from Fluka. All other chemicals were from Roth.

General genetic manipulation. Isolation of E. coli plasmid DNA, digestion of DNA with restriction endonucleases and Southern hybridization were carried out according to the directions of the suppliers of kits, enzymes and reagents (Amersham Pharmacia). Southern hybridization was performed with Hybond-N nylon membranes (Amersham Pharmacia). Probes were labelled with digoxigenin (DIG) by using a DIG labelling and detection kit (Roche). Restriction mapping and other routine molecular biology methods were performed as described by Sambrook et al. (1989). Protoplast formation, transformation and regeneration of protoplasts from Str. viridochromogenes Tü57 were carried out by standard procedures (Hopwood et al., 1985). PCR was carried out using a Perkin Elmer GeneAmp 2400 thermal cycler. The conditions were as described by Bechthold \& Floss (1994).

DNA sequencing and computer-assisted sequence analysis. DNA was sequenced by the dideoxynucleotide chain-termination method using thermosequenase (Amersham Pharmacia). Universal and reverse primers (Amersham Pharmacia) were used. Sequencing reactions were performed on an automated sequencer (Vistra 725) from Molecular Dynamics and on an ABI sequencer from 4-Base Lab. DNA sequences were analysed using the DNASIS software package (version 2, 1995; Hitachi Software Engineering). BLASTX analysis (Altschul et al., 1997) was used to search the GenBank CDC translations + PDB + SWISS-PROT + Spupdate + PIR, release 2.0 for matching sequences.

Generation of a chromosomal aviG1 mutant of Str. viridochromogenes Tü57. For generation of a chromosomal aviG1 mutant of Str. viridochromogenes Tü57 by homologous recombination, plasmid pMIK1 was constructed. A $7 \cdot 7 \mathrm{~kb}$ Bam HI fragment containing the entire methyltransferase gene was cloned into pBluescript SK - to create plasmid B7. B7 was digested with BglII and SpeI (the SpeI site is located within the polylinker of pBluescript $\mathrm{SK}-$ ), treated with Klenow frag- 
Table 1. Most important plasmids used in this study

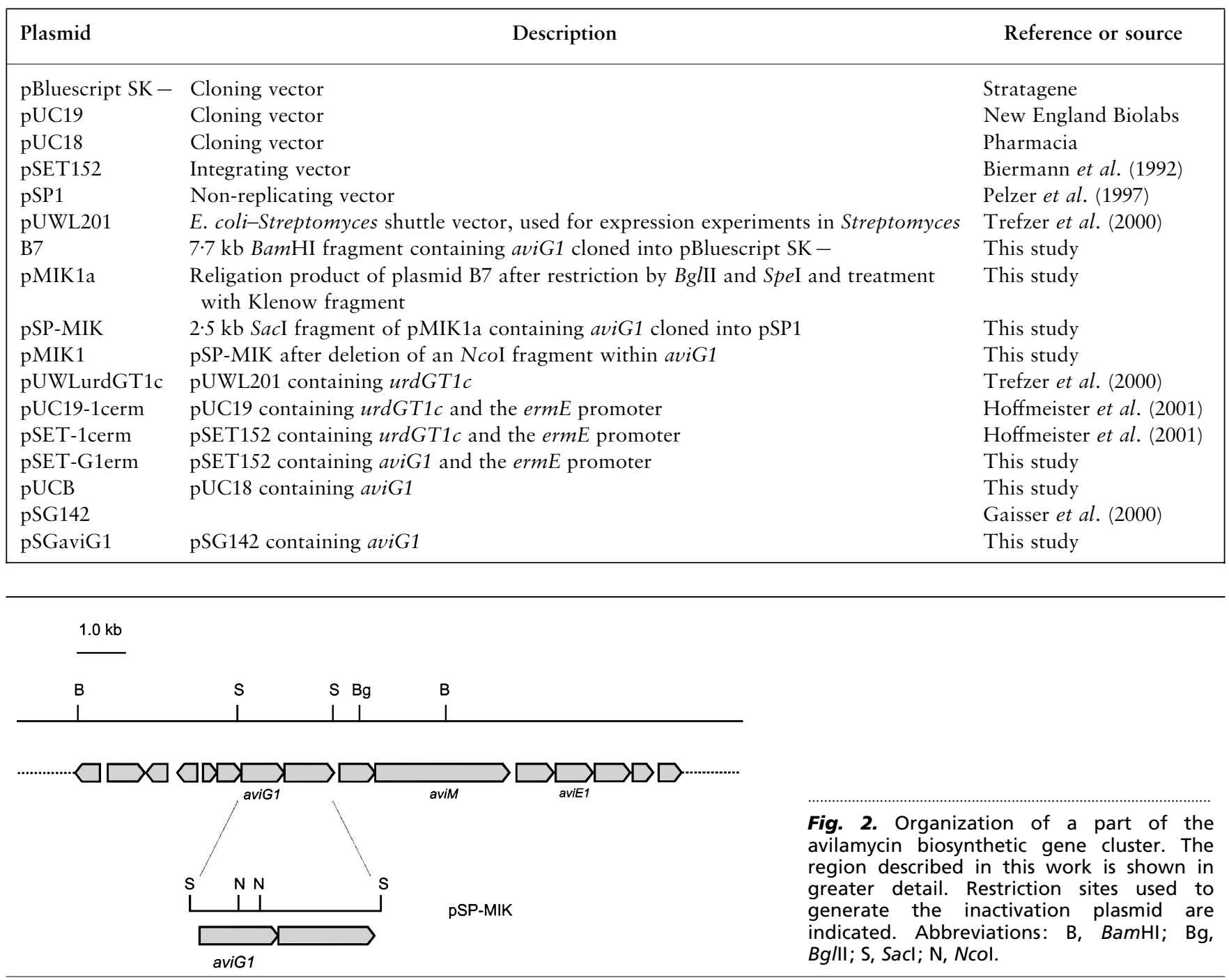

ment and religated to generate pMIK1a. A $2 \cdot 5 \mathrm{~kb}$ SacI fragment of pMIK1a, containing aviG1, was ligated into the corresponding sites of pSP1, generating pSP-MIK (Fig. 2). pSPMIK was digested with $N c o$ I to delete a 285 bp fragment within aviG1, resulting in plasmid pMIK1. pMIK1 was used to transform protoplasts of Str. viridochromogenes Tü57. Selection of primary transformants was performed on erythromycin-containing plates. For characterization of transformants by Southern hybridization, an internal $1.7 \mathrm{~kb}$ SmaI fragment of the ermE gene of pSP1 and the internal $2.2 \mathrm{~kb}$ SacI fragment of pMIK1 were used as probes. After screening for erythromycin-sensitivity, a double cross-over mutant, named Str. viridochromogenes GW1, was obtained. Chromosomal DNA from this mutant was analysed by Southern hybridization using the $2.2 \mathrm{~kb}$ Sacl fragment as probe. The result of Southern hybridization was confirmed by PCR using oligonucleotide primers HaloF (5'-GCCGAGCAAAGCTTGGAGAATCAT- $\left.3^{\prime}\right)$ and HaloR (5'-TGGTGGCATGCGATGTCACCTCC-3').

Complementation of mutant Str. viridochromogenes GW1. For complementation of mutant Str.viridochromogenes GW1, plasmid pSET-G1erm was constructed. pUWLurdGT1c (Trefzer et al., 2000) was subjected to a KpnI/XbaI restriction digestion to obtain a $1.6 \mathrm{~kb}$ fragment that covers the complete reading frame urdGT1c as well as the ermE promoter sequence. This fragment was inserted in the multiple cloning site of pUC19 cleaved with the same enzymes. This plasmid was named pUC19-1cerm. The urdGT1c gene and the ermE promoter were excised by EcoRI restriction and ligated into pSET152 to create plasmid pSET-1cerm. aviG1 was PCRamplified to introduce $\mathrm{MunI}$ and $\mathrm{Xba \textrm {I }}$ restriction sites by using oligonucleotide primers AviG1F (5'-AGATGTCAATTGCTGGCTCA-3') and AviG1R (5'-TGGTGTCTA $\overline{\text { GAGA- }}$ TGTCACCTCC-3' (restriction sites are underlined). Plasmid pSET-1cerm was digested with MunI and XbaI to remove urdGT1c, and aviG1 was cloned behind the ermE promoter in place of $u r d G T 1 c$ to create the integration plasmid pSETG1erm. After transformation of mutant Str. viridochromogenes GW1 by pSET-G1erm, several colonies were obtained and grown at $28{ }^{\circ} \mathrm{C}$ in liquid medium as described above. Extracts of cultures were analysed by TLC, bioassay and HPLC-UV (see Fig. 4).

Complementation of the erythromycin eryBIII mutant 335. For complementation of the eryBIII mutant 355, a HindIII restriction site $5^{\prime}$ to the ribosome-binding site and an SphI restriction site $3^{\prime}$ to the termination codon were introduced 
into aviG1 by using PCR. The fragment was cloned into the HindIII and SphI sites of pUC18 to generate pUCB, which was digested with HindIII, followed by a fill-in reaction (Sambrook et al., 1989). After BamHI digestion, the fragment harbouring aviG1 was ligated into pSG142, previously digested with NdeI, followed by treatment with Klenow polymerase and BglII digestion. The cloning region around the former NdeI site in the resulting plasmid, pSGaviG1, was sequenced, revealing the deletion of $9 \mathrm{nt}$ at the NdeI/HindIII fusion site. Plasmid pSGaviG1 was used to transform the Sac. erythraea eryBIII mutant 335 as described by Gaisser et al. (1998). The presence of the eryBIII mutation was confirmed using chromosomal DNA of a Sac. erythraea eryBIII mutant and the transformed strain containing aviG1 as template. PCR reactions were carried out as described previously (Gaisser et al., 1998) and the sequence of the PCR fragments was confirmed. The PCR fragment obtained with chromosomal DNA of Sac. erythraea eryBIII mutant as template was also used as a probe in Southern hybridization experiments with BamHI-digested genomic DNA of Sac. erythraea NRRL2338, eryBIII mutant 355 and eryBIII mutant 355 harbouring aviG1. No difference in the pattern of the labelled DNA bands was detected. These results indicated that the eryBIII gene was not involved in a recombination event.

Analysis of avilamycin and erythromycin derivatives. For avilamycin production, Str. viridochromogenes Tü57 and mutant Str. viridochromogenes GW1 were grown as described above. Cultures were extracted with an equal volume of ethyl acetate. After evaporation of the solvent the dried extracts were redissolved in methanol. TLC analysis was carried out on silica gel plates (silica gel $60 \mathrm{~F} 254$, Merck) with $\mathrm{CH}_{2} \mathrm{Cl}_{2}$ / $\mathrm{CH}_{3} \mathrm{OH}(9: 1, \mathrm{v} / \mathrm{v})$ as solvent. Avilamycin derivatives could be detected after treatment with anisaldehyde $/ \mathrm{H}_{2} \mathrm{SO}_{4}$ (Braun, 1995).

HPLC analysis was performed on a Waters Alliance HT Liquid Chromatograph with a diode-array detector and a ProC18, $50 \times 4 \mathrm{~mm}$ column. The detection wavelength was $220 \mathrm{~nm}$. The solvent system was as follows: Solvent A, acetonitrile $/\left[\mathrm{H}_{2} \mathrm{O} / \mathrm{H}_{3} \mathrm{PO}_{4}(99 \cdot 9: 0 \cdot 1)\right], 5: 95(\mathrm{v} / \mathrm{v})$; solvent $\mathrm{B}$ : acetonitrile $/\left[\mathrm{H}_{2} \mathrm{O} / \mathrm{H}_{3} \mathrm{PO}_{4}(99 \cdot 9: 0 \cdot 1)\right], 42: 58(\mathrm{v} / \mathrm{v})$; non-linear gradient, $0-100 \%$ solvent $\mathrm{B}$ over $16 \mathrm{~min}$ at a flow rate of $1.2 \mathrm{ml} \mathrm{min}{ }^{-1}$. Avilamycin A was identified by comparison with an authentic sample. For erythromycin A production, culture supernatants were treated as described previously and the extracts were analysed using electrospray MS (ES-MS; Gaisser et al., 1998).

\section{RESULTS AND DISCUSSION}

\section{Sequence analysis}

Having cloned and sequenced the avilamycin biosynthetic gene cluster (Gaisser et al., 1997; Weitnauer et al. 2001), our work now was aimed at characterizing further genes involved in avilamycin biosynthesis. Database comparison with the deduced product of aviG1 using BLASTP and BLASTX revealed similarities between AviG1 and several C-methyltransferases. The most similar proteins found were TylCIII from Streptomyces fradiae (66\% identical amino acids; Bate et al., 2000) and EryBIII from Sac. erythraea (64\% identical amino acids; Haydock et al., 1991; Gaisser et al., 1998). Homology was also found to ORF14 from the chloroeremomycin producer Amycolatopsis orientalis (29\% identical amino acids; Chen et al., 2000). The C-methyltrans-
1

50 EYYBIII M IFLVGLGKCR ICGNHDLESV LHLGDQALTG VFPRNRDEIV

TYICIII VPAVPREDQM I....ISACR VCGNRELLPV LDLGEQALTG VFPRTREETV AVIGI MSTT GHSTVIDRCR ICDNTELLPV LDLGPQALTG VFPRTRGEDV

ORF14 $\sim \sim \sim \sim \sim \sim \sim \sim \sim$ MSVTSQCR ICDGT.VKEF IDFGRQPLSD AFVVPGDEKG 51

ErYBIII PSVPLELVKC APPGCGLVQL RESADFGLMY NEGYGYRSGI RPFMINHLHG TYICIII PSIPLELVKC SPQGCGLVQL RHTPDPGLMY GEGYGYRSGI RPFMIGHLRR AVIGI PYVPLELVRC SPGGCELVQL RHTADFGLMY GEGYGYRSSL NRSMADHLRG ORF14 EFF.FRLATG ICDSCTMVQL MEEVPRDLMF HDAYPYLSSG SAFMRTHFNE 101

ErYBIII KVAKLRGMVP VGPDDIVVDI GSND\$TLLRG YLPDAPKLAG HDLVGEKFRD

TYICIII KVAAIRELVD LGPDDIVLDI GSNDATLLKA Y.PEGPRLVG IDPSGDKFRE AvIGI KVAAITGLVD LGPGDIVVDI GSND\&TLLAA YPADGPRLVG YDPATVFAA

ORF14 LAKRLLTTEL TGEDPFIVEL GCNDGIMLKA MAEAGVRQLG VEPSGSVADL 151 motifI 200

EYYBIII LYPPEADLVT GFF.SADAFE ERYGERRAKV VTSIAMFYDL PEPMRFMRDV TYICIII LYPPHAELIA EYF.SRDVFT ARFGTRRARV ITSIAMFYDL PDPLAFMRDV

AvIGI SYPPGVELIP DFF.AYDLL. ...GGRRAKV VTSIAMFYDL PRPMEFMREV

ORF14 AAAKGIRVRK DFFEEATAAD IRETDGPADV IYAANTLCHI PYMDSILKGV 201

250

EYYBIII HDILADDGLW LMEQSYLPSM LDAGAYDYVC HEHLEYYALA QIEWMAQRVG

TYICIII HDVLADDGIW VMEQSYLPAM LEADAYDIVC HEHLEYYALQ QIEWMAERAG AvIGI GRLLTDDGIW VTEQSYLPAM LHACAYDYVC HEHLDYYGLR QIEWMAERTG ORF14 TTLLGPNGVF VFEDPYLGDI VERTSFDdIY DEHFFFFTAR SVQEMAKRNG 251 motif II 300

EYYBIII LKVVDAEITD VYGGSL CAVL AKQGSGHPVD EAGLERIRAR EAAAKLDTMA TYICIII LTVLRAFLTD VYGGSLLVTL ARASSPHPRD EAGPARIRAR ETEAKINTMA AvIGI LKVVDAETTP VYGGSL \$LVL ARRGSSRQVN EPALARIRAG ETD.....L ORF14 LELVDVERIP VHGGEVRYTL ALAGARQPTE . .AVAELLAW EAERKLAEYA 301 motif III 350

EYYBIII PYEAFARETE RQRDQLLEFL AKSRAEGKLT LGYGASTKGN VILQYCGLTE

TYICIII PFEEFARRVE HQRDALRDFL DRSRAAGRLT LGYGASTKGN VILQYCGIGE

AVIGI PYAEFARRTE ESRDRLLEFL TASRDKGLHT LGYGASTKGN VILQYCGLDE

ORF14 TLERFATNVK KIKDDLIALL TKLRAEGKRV VGYGATAKSA TVTNFCGITP 351

400

ErYBIII QDLPCIGEVS PEKSGCYTPG TGIPIVSEEE AKSRRPDQLL VLPWIYRDGF

TYICIII RDLPCIGEVS PEKAGRFTPG TGIPIVSEED AKAMRPDQLL VLPWIYREGF AviGI TLLPCIAEVN EDKFGCYTPG TNIPIVSEEE ARALEPDQFL VLPWIYRDAM ORF14 DLVEFISDTT PAKQNRLSPG QHIPVREPKE FAADYPDYAL LFAWNHADEI 401

EYYBIII VEREQEFLAG GGKLIFPLPR LEVV

TYICIII VERERDFLAG GGRLVFPLPR LDVV*

AVIGI VARERDFLAS GGSLVFPLPT LEVV*

ORF14 MNAEQAFRDA GGQWILYVPN VHVS*

Fig. 3. Comparison of the aviG1 gene product with the known C-methyltransferases EryBIII, TylCIII and ORF14. Motifs I-III (Kagan \& Clarke, 1994) are indicated.

ferase activity of this enzyme has been demonstrated. AviG1, TylCIII, EryBIII and ORF14 contain three sequence regions which are usually found in $S$-adenosylmethionine-dependent methyltransferases (Kagan \& Clarke, 1994) (Fig. 3). Motif I, which has been defined as a nine residue block with the consensus sequence $(\mathrm{V} / \mathrm{I} / \mathrm{L})(\mathrm{L} / \mathrm{V})(\mathrm{D} / \mathrm{E})(\mathrm{V} / \mathrm{I}) \mathrm{G}(\mathrm{G} / \mathrm{C}) \mathrm{G}(\mathrm{T} / \mathrm{P}) \mathrm{G}$, is located at position 111-120 in AviG1 (VVDIGSNDG) with a conserved glycine residue at position 5 . This motif has been suggested to be a possible component of the $S$ adenosylmethionine-binding site (Schluckebier et al., 

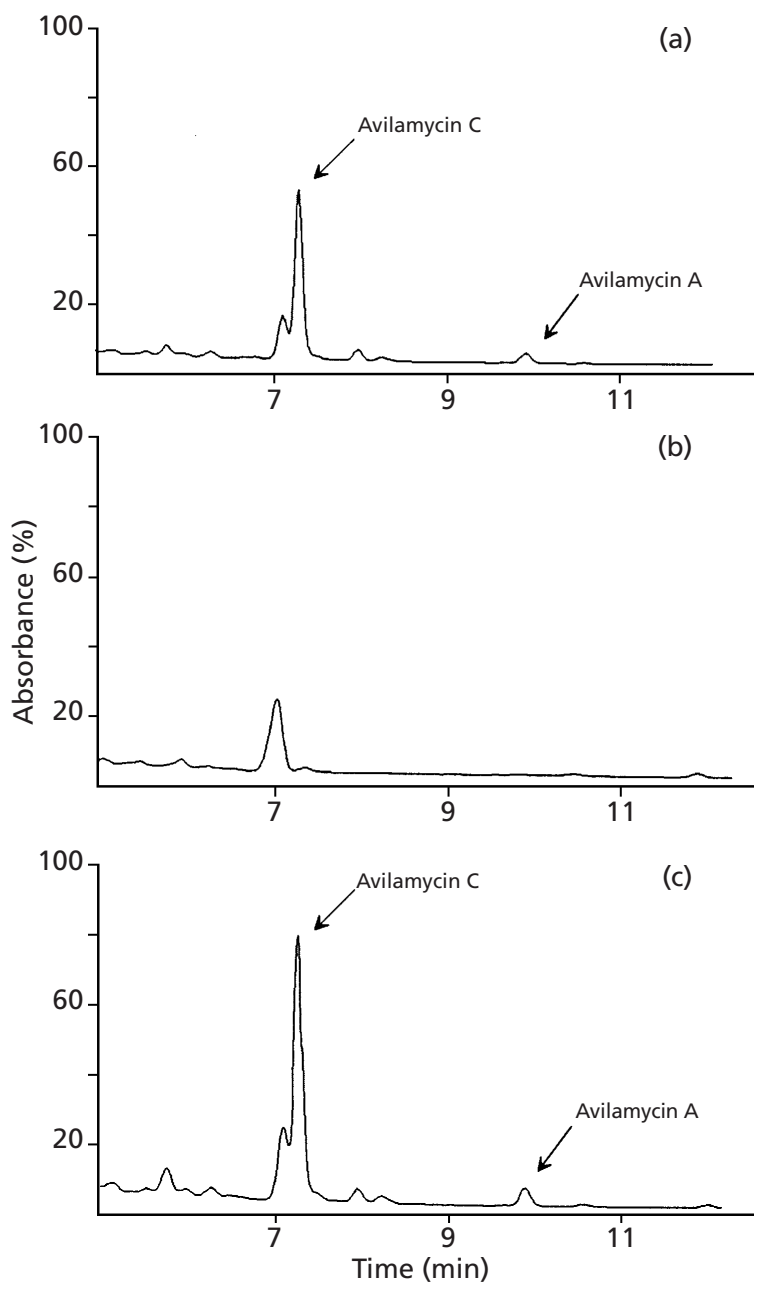

Fig. 4. HPLC chromatograms of extracts of the wild-type strain Str. viridochromogenes Tü57 (a), mutant Str. viridochromogenes GW1 (b) and the complemented mutant Str. viridochromogenes GW1 (c), showing characteristic signals for avilamycin $A$ and avilamycin $\mathrm{C}$. In the chromatogram of mutant Str. viridochromogenes GW1, no signal corresponding to avilamycin derivatives could be detected.

1995). An aspartate as a conserved acidic residue is found 17 residues C-terminal to this motif, which is characteristic for methyltransferases and which, as the crystal structures indicate, makes contact with bound $S$ adenosylmethionine (Schluckebier et al., 1995). Putative second and third motifs are indicated in Fig. 3.

\section{Inactivation of the aviG1 gene}

To assay the role of aviG1 in avilamycin biosynthesis, pMIK1 was constructed containing aviG1 with an inframe deletion. After transformation of Str. viridochromogenes Tü57 by pMIK1, several erythromycinresistant colonies were obtained. Integration of pMIK1 into the chromosome at the expected position was verified by Southern hybridization (data not shown). To allow for the second recombination event, integrants were screened for erythromycin sensitivity. The chromo- somal mutation in mutant Str. viridochromogenes GW1, which showed erythromycin sensitivity, was analysed by Southern hybridization (data not shown). The internal $2 \cdot 2 \mathrm{~kb}$ SacI fragment of pMIK1 was used to probe EcoRI-digested chromosomal DNA. Analysis of the wild-type Str. viridochromogenes Tü57 showed one signal consisting of the two expected fragments of $1.7 \mathrm{~kb}$ after hybridization. When chromosomal DNA from clone Str. viridochromogenes GW1 was treated in the same way, two hybridization signals were obtained, one of $1.7 \mathrm{~kb}$ and one of $1.5 \mathrm{~kb}$, indicating that the $285 \mathrm{bp}$ $\mathrm{NcoI}$ fragment was deleted. To confirm the presence of the deletion within the chromosome of Str. viridochromogenes GW1, chromosomal DNA of the mutant and the wild-type strain was subjected to PCR analysis. The size of the amplified fragment $(0.9 \mathrm{~kb})$ detected in the mutant strain was identical to that generated with the inactivation construct pMIK1, while the wild-type strain gave a PCR product of the expected higher size $(1 \cdot 2 \mathrm{~kb})$ (data not shown). The products accumulated by this mutant were also analysed for antibacterial activity. After cultivation of the mutant, culture supernatants were extracted as described in Methods and the extract was tested for antibiotic activity against Bacillus subtilis. No inhibitory effect on the growth of B. subtilis was observed for the pMIK1 mutant extract, but extracts of the wild-type showed inhibitory effects. In addition, TLC and HPLC analysis of the extract of mutant Str. viridochromogenes GW1 did not reveal the presence of any avilamycin derivatives (Fig. 4). Assuming that AviG1 is responsible for methylation at position C3 during 2-deoxy-D-evalose biosynthesis, an explanation for the breakdown of avilamycin biosynthesis could be that either the synthesis of evalose or the attachment of this sugar is blocked in the methyltransferase mutant. We also did not detect any orsellinic acid derivative in the mutant. We assume that the expression of aviM, encoding an orsellinic acid synthase, is suppressed in the absence of the saccharide moiety.

\section{Complementation of mutant Str. viridochromogenes GW1}

To determine clearly that the mutation event only affected the desired gene and not other genes, aviG1 was ligated downstream of the ermE up-promoter, cloned into the integration plasmid pSET152 and introduced by protoplast transformation into the corresponding GW1 mutant. Analysis of extracts of complemented mutants by TLC and HPLC-UV clearly showed that avilamycin $\mathrm{C}$ and avilamycin A production was restored (Fig. 4). Thus, we could rule out any upstream or downstream effects.

\section{Complementation of the erythromycin eryBIII mutant 335}

To demonstrate the complementation of the Sac. erythraea eryBIII mutant 335, plasmid pSGaviG1 was isolated which places the expression of aviG1 under the control of the activator ActII-ORF4 (Rowe et al., 1998). 


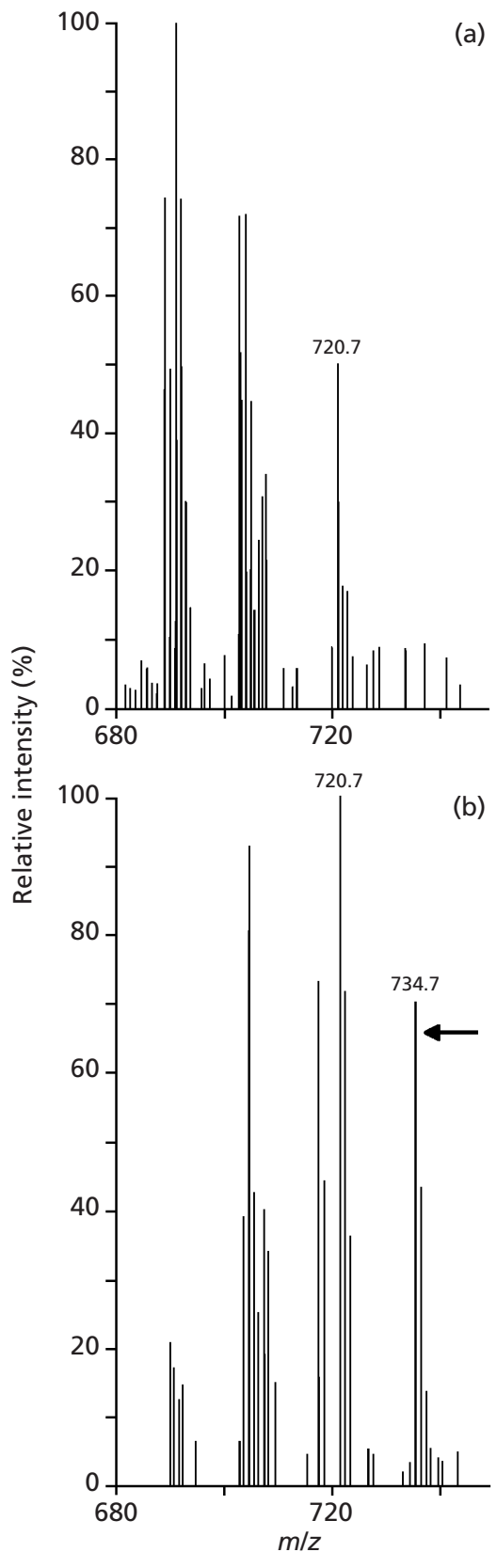

Fig. 5. ES-MS spectra of extracts of eryBIII mutant 335 (a) and eryBIII mutant 335 containing aviG1 (b), showing signals characteristic for 3"-C-desmethyl erythromycin A ( $\mathrm{m} / \mathrm{z}$ 720.7) and erythromycin A (m/z 734.7).

Extracts of culture supernatants of the wild-type strain, eryBIII mutant 355 and eryBIII mutant 355 containing aviG1 were analysed by ES-MS. Extracts of the wildtype strain gave the expected signal for erythromycin A at $m / z 734 \cdot 7$. Mutant 355 gave a signal at $m / z 720 \cdot 7$, which indicates the formation of 3 "-C-desmethyl erythromycin A (Gaisser et al., 1998). The MS data obtained with the eryBIII mutant 355 containing aviG1 showed peaks at $\mathrm{m} / z 720 \cdot 7$ and $734 \cdot 7$, indicating that erythromycin A as well as 3"-C-desmethyl erythromycin A are formed (Fig. 5). To confirm that methylation occurred at 3"-C of L-mycarose, MS/MS analyses of the peaks at $m / z 734.7$ and $m / z 720 \cdot 7$ were performed. In both cases, a daughter ion at $\mathrm{m} / z 576.5$ was detected unambiguously, indicating the loss of the 3 "-C sugar (data not shown). From these data we can conclude that the expression of aviG1 did allow complementation of the eryBIII mutation. AviG1 seems to be able to participate in L-mycarose biosynthesis, providing further support for the proposal that AviG1 encodes a Cmethyltransferase capable of acting on position $\mathrm{C} 3$ of an activated sugar. Since L-mycarose and 2-deoxy-D-evalose differ mainly in their stereochemistry at position C5, AviG1 is therefore most likely involved in the synthesis of 2-deoxy-D-evalose. However, results using bioassays revealed that the expression of aviG1 restored erythromycin production just to a very small extent (data not shown). No reproducible difference could be detected between the size of the haloes of Sac. erythraea 335 and Sac. erythraea 335 expressing aviG1 (data not shown).

\section{REFERENCES}

Altschul, S. F., Madden, T. L., Schaffer, A. A., Zhang, J., Zhang, Z., Miller, W. \& Lipman, D. J. (1997). Gapped BLAST and PSI-BLAST: a new generation of protein database search programs. Nucleic Acids Res 25, 3389-3402.

Bate, N., Butler, A. R., Smith, I. P. \& Cundliffe, E. (2000). The mycarose-biosynthetic genes of Streptomyces fradiae, producer of tylosin. Microbiology 146, 139-146.

Bechthold, A. \& Floss, H. (1994). Overexpression of the thiostrepton resistance genes from Streptomyces azureus in Escherichia coli and characterization of recognition sites of the 23S rRNA A1067 2'-methyltransferase in the GTPase centre of $23 S$ ribosomal RNA. Eur J Biochem 224, 431-437.

Biermann, M., Logan, R., O’Brien, K., Seno, E. T., Nagaraja, R. \& Schoner, B. E. (1992). Plasmid cloning vectors for the conjugal transfer of DNA from Escherichia coli to Streptomyces spp. Gene $166,3-49$.

Braun, C. (1995). Untersuchungen an einem Antibiotikum aus der Orthosomycingruppe. Diploma thesis, Universität Tübingen, Germany.

Buzzetti, F., Eisenberg, F., Grant, H. N., Keller-Schierlein, W., Voser, W. \& Zähner, H. (1968). Avilamycin. Experimentia 24, 320-324.

Chen, H., Thomas, M. G., Hubbard, B. K., Losey, H. C., Walsh, C. T. \& Burkart, M. D. (2000). Deoxysugars in glycopeptide antibiotics: enzymatic synthesis of TDP-L-epivancosamine in chloroeremomycin biosynthesis. Proc Natl Acad Sci USA 97, 11942-11947.

Flett, F., Mersinias, V. \& Smith, C. P. (1997). High efficiency intergenic conjugal transfer of plasmid DNA from Escherichia coli to methyl DNA-restricting streptomycetes. FEMS Microbiol Lett 155, 223-229.

Foster, D. R. \& Rybak, M. J. (1999). Pharmacologic and bacteriologic properties of SCH27899 (Ziracin), an investigational antibiotic from the everninomicin family. Pharmacotherapy 19, 1111-1117.

Fuchs, P. C., Barry, A. L. \& Brown, S. D. (1999). In vitro activities of SCH27899 alone and in combination with 17 other antimicrobial agents. Antimicrob Agents Chemother 43, 2996-2997.

Gaisser, S., Trefzer, A., Stockert, S., Kirschning, A. \& Bechthold, A. 
(1997). Cloning of an avilamycin biosynthetic gene cluster from Streptomyces viridochromogenes Tü57. J Bacteriol 179, 62716278.

Gaisser, S., Bohm, G. A., Doumith, M., Raynal, M. C., Dhillon, N., Cortes, J. \& Leadlay, P. F. (1998). Analysis of eryBI, eryBIII and eryBVII from the erythromycin biosynthetic gene cluster in Saccharopolyspora erythraea. Mol Gen Genet 258, 78-88.

Gaisser, S., Reather, J., Wirtz, G., Kellenberger, L., Staunton, J. \& Leadlay, P. F. (2000). A defined system for hybrid macrolide biosynthesis in Saccharopolyspora erythraea. Mol Microbiol 36, 391-401.

Haydock, S. F., Dowson, J. A., Dhillon, N., Roberts, G. A., Cortes, J. \& Leadlay, P. F. (1991). Cloning and sequence analysis of genes involved in erythromycin biosynthesis in Saccharopolyspora erythraea: sequence similarities between EryG and a family of $S$-adenosylmethionine-dependent methyltransferases. Mol Gen Genet 230, 120-128.

Hessler, P. E., Larsen, P. E., Constantinou, A. I., Schram, K. H. \& Weber, J. M. (1997). Isolation of isoflavones from soy-based fermentations of the erythromycin-producing bacterium Saccharopolyspora erythraea. Appl Microbiol Biotechnol 47, 398404.

Hoffmeister, D., Ichinose, K. \& Bechthold, A. (2001). Two sequence elements of glycosyltransferases involved in urdamycin biosynthesis are responsible for substrate specificity and enzymatic activity. Chem Biol 8, 557-567.

Hopwood, D. A., Bibb, M. J., Chater, K. F. \& 7 other authors (1985). Genetic Manipulation of Streptomyces: a Laboratory Manual. Norwich: John Innes Foundation.

Jones, R. N., Marshall, S. A. \& Erwin, M. E. (1999). Antimicrobial activity and spectrum of SCH27899 (Ziracin) tested against grampositive species including recommendations for routine susceptibility testing methods and quality control. Quality Control Study Group. Diagn Microbiol Infect Dis 34, 103-110.

Kagan, R. M. \& Clarke, S. (1994). Widespread occurrence of three sequence motifs in diverse $S$-adenosylmethionine-dependent methyltransferases suggests a common structure for these enzymes. Arch Biochem Biophys 310, 417-427.

Lambalot, R. H., Cane, D. E., Aparicio, J. J. \& Katz, L. (1995). Overproduction and characterization of the erythromycin C-12 hydroxylase, EryK. Biochemistry 34, 1858-1866.

Lin, C., Gupta, S., Loebenberg, D. \& Cayen, M. N. (2000). Pharmacokinetics of an everninomicin (SCH 27899) in mice, rats, rabbits, and cynomolgus monkeys following intravenous administration. Antimicrob Agents Chemother 44, 916-919.

Paulus, T. J., Tuan, J. S., Luebke, V. E., Maine, G. T., DeWitt, J. P. \& Katz, L. (1990). Mutation and cloning of ery $G$, the structural gene for erythromycin O-methyltransferase from Saccharopolyspora erythraea, and expression of ery $G$ in Escherichia coli. J Bacteriol 172, 2541-2546.
Pelzer, S., Reichert, W., Huppert, M., Heckmann, D. \& Wohlleben, W. (1997). Cloning and analysis of a peptide synthetase gene of the balhimycin producer Amycolatopsis mediterranei DSM5908 and development of a gene disruption/replacement system. $J$ Biotechnol 56, 115-128.

Rowe, C. J., Cortes, J., Gaisser, S., Staunton, J. \& Leadlay, P. F. (1998). Construction of new vectors for high-level expression in actinomycetes. Gene 216, 215-223.

Salah-Bey, K., Doumith, M., Michel, J. M., Haydock, S., Cortes, J., Leadlay, P. F. \& Raynal, M. C. (1998). Targeted gene inactivation for the elucidation of deoxysugar biosynthesis in the erythromycin producer Saccharopolyspora erythraea. Mol Gen Genet 257, 542-553.

Sambrook, J., Fritsch, E. F. \& Maniatis, T. (1989). Molecular Cloning: a Laboratory Manual, 2nd edn. Cold Spring Harbor, NY: Cold Spring Harbor Laboratory.

Schluckebier, G., O'Gara, M., Saenger, W. \& Cheng, X. (1995). Universal catalytic domain structure of AdoMet-dependent methyltransferases. J Mol Biol 247, 16-20.

Stassi, D., Donadio, S., Staver, M. J. \& Katz, L. (1993). Identification of a Saccharopolyspora erythraea gene required for the final hydroxylation step in erythromycin biosynthesis. J Bacteriol 175, 182-189.

Summers, R. G., Donadio, S., Staver, M. J., Wendt-Pienkowski, E., Hutchinson, C. R. \& Katz, L. (1997). Sequencing and mutagenesis of genes from the erythromycin biosynthetic gene cluster of Saccharopolyspora erythraea that are involved in L-mycarose and D-desosamine production. Microbiology 143, 3251-3262.

Trefzer, A., Hoffmeister, D., Kunzel, E. \& 8 other authors (2000). Function of glycosyltransferase genes involved in urdamycin A biosynthesis. Chem Biol 7, 133-142.

Wang, E., Simard, M., Bergeron, Y., Beauchamp, D. \& Bergeron, M. G. (2000). In vivo activity and pharmacokinetics of ziracin (SCH27899), a new long-acting everninomicin antibiotic, in a murine model of penicillin-susceptible or penicillin-resistant pneumococcal pneumonia. Antimicrob Agents Chemother 44, 1010-1018.

Weber, J. M., Leung, J. O., Swanson, S. J., Idler, K. B. \& McAlpine, J. B. (1991). An erythromycin derivative produced by targeted gene disruption in Saccharopolyspora erythraea. Science 252, 114-117.

Weitnauer, G., Mühlenweg, A., Trefzer, A. \& 7 other authors (2001). Biosynthesis of the orthosomycin antibiotic avilamycin A: deductions from the molecular analysis of the avi biosynthetic gene cluster of Streptomyces viridochromogenes Tü57 and production of new antibiotics. Chem Biol 8, 569-581.

Wright, D. E. (1979). The orthosomycins, a new family of antibiotics. Tetrabedron 35, 1207-1237.

Received 18 May 2001; revised 13 September 2001; accepted 15 October 2001. 